\title{
Role of Olf-1 and Pax-6 Transcription Factors in Neurodevelopment
}

\author{
Janine A. Davis and Randall R. Reed \\ The Howard Hughes Medical Institute, Department of Molecular Biology and Genetics and Department of Neuroscience, \\ The Johns Hopkins University School of Medicine, Baltimore, Maryland 21205
}

The Olf-1 transcription factor is expressed in olfactory sensory neurons where it regulates the expression of genes that encode components of the odorant signal transduction cascade and contributes to the terminal phenotype of these sensory neurons. We examined the pattern of expression of Olf-1 protein during mouse embryogenesis and observed Olf-1 expression transiently in a subset of neural precursor cells in the CNS and peripheral nervous system. The expression of Olf-1 protein was enriched in sensory components and coincided with postmitotic cells and the initiation of overt differentiation within the nervous system. The spatial and temporal patterns of Olf-1 expression during development suggest a role in neurogenesis that is common among different neural cell types. In parallel, the expression pattern of Pax-6, a transcription factor that is widely expressed in the developing nervous system, including the visual and olfactory systems, was examined with a C-terminal antibody. In the retina, Pax- 6 protein is detected in the lens, the cornea, and the neural and pigmented retinas. In the olfactory epithelium, Pax-6 protein is expressed exclusively in cells of non-neuronal lineage, including sustentacular cells, basal cells, and Bowman's glands. The nonoverlapping, cellular localization patterns of Pax- 6 and Olf- 1 demarcate distinct cell lineages within the developing olfactory epithelium.

Key words: neurodevelopment; transcription factors; Pax-6; Olf-1; sensory neurons; olfactory epithelium
The developing vertebrate nervous system acquires its characteristic form and diverse cellular composition via extrinsic and intrinsic cues generated by a programmed pattern of gene expression. The olfactory system, a component of the CNS, provides a useful model for studying the nature of the cues involved in neurogenesis, in light of its unique capacity to replace continually its neurons throughout adult life (Moulton, 1974; Graziadei and Monti Graziadei, 1978). The replacement of olfactory neurons with an average lifespan of 60-90 d (Costanzo and Graziadei, 1987 ) is regulated by proliferative and differentiative events.

The olfactory sensory tissue originates from ectodermally derived neurogenic placodes and is composed of three basic cell types that form a pseudostratified epithelium: the odorant receptor-containing neuron, the sustentacular or support cell, and two classes of basal cells, known as globose (GBC) and horizontal (HBC) basal cells (Costanzo and Graziadei, 1987). In Xenopus laevis, olfactory neurons and basal cells derive from neuronal ectoderm, whereas sustentacular cells are born from nonneuronal ectodermal precursors, although the processes in mammals that lead to olfactory epithelial establishment remain largely unknown (Klein and Graziadei, 1983). In the adult, olfactory neurons are continually replaced from a resident population of proliferative GBCs (Moulton, 1974; Graziadei and Monti Graziadei, 1978; Mackay-Sim and Kittel, 1991). In contrast, it has been suggested that HBCs and/or mucus-secreting Bowman's glands underlying the epithelium give rise to sustentacular cells in the

\footnotetext{
Received March 7, 1996; revised May 15, 1996; accepted May 22, 1996.

This work was supported by grants from National Institutes of Health and the Human Frontiers Science Program to R.R.R. We are indebted to our family members for their continued support and patience, and we are grateful for the contributions of Karen Schrader, Tim Koenig, Se-Jin Lee, Pat Wilcox, and Diane Stewart. We thank Mark Molliver, Gabriele Ronnett, and the members of the Reed laboratory for stimulating and supportive discussions.

Correspondence should be addressed to Randall R. Reed, Room 800-PCTB, 725 North Wolfe Street, Baltimore, MD 21205.

Copyright (C) 1996 Society for Neuroscience 0270-6474/96/165082-13\$05.00/0
}

adult (Mulvaney and Heist, 1971; Hempstead and Morgan, 1983; Mackay-Sim and Kittel, 1991; Suzuki and Takeda, 1991).

The generation and replacement of cells in the epithelium must be regulated in a dynamic fashion to maintain proper function in olfactory tissue. The importance of extrinsically derived trophic factors and receptors (fibroblast growth factor, transforming growth factor- $\beta$, and nerve growth factor receptor) in modulating olfactory neuronal development has been described recently (Mahanthappa and Schwarting, 1993; DeHamer et al., 1994; Calof, 1995; Roskams et al., 1996). Transcription factors play an equally important role as intrinsic regulators of neurogenesis. The identification of vertebrate Pax genes was based on the conservation of the Paired domain first discovered in several Drosophila segmentation genes (Gruss and Walther, 1992). Mouse Pax-6 mRNA was detected early in the optic and olfactory pits and later in the developing eye, olfactory epithelium (OE), and olfactory bulb by in situ hybridization (Walther and Gruss, 1991). Mice with mutations in the Pax-6 gene (small eye, Sey) failed to form lens and nasal placodes, resulting in the absence of eyes and nose (Thieler et al., 1978; Hogan et al., 1986; Hill et al., 1991), whereas mutations in the human Pax-6 gene lead to malformation of eye structures in a disease known as aniridia (Glaser et al., 1992; Hanson et al., 1993).

An olfactory neuronal transcription factor, Olf-1 (Wang and Reed, 1993), binds to a conserved, cis-acting element upstream of several olfactory neuronal-specific genes (Kudrycki et al., 1993; Wang et al., 1993), suggesting a role in regulating genes that function in odorant detection. The expression of Olf- 1 in adult olfactory neurons and their neuronal precursors suggested that Olf-1 may also have a role in the continual replacement of these sensory neurons. The similarities between the continual generation of neurons in adult $\mathrm{OE}$ and neurogenesis throughout the embryo-proliferation, exit from the cell cycle, commencement of a neuronal phenotype, and turnover-led us to examine whether 
Olf-1 may play a more general role in neurodevelopment. In parallel, we investigated the pattern of Pax-6 expression, a transcription factor known to be important in sensory organ development and expressed in embryonic olfactory tissue, to determine the role this protein plays in olfactory tissue. Generation of an antibody to the Olf- 1 and Pax- 6 transcription factors allowed us to demonstrate that these transcription factors define distinct and nonoverlapping cell lineages within the $\mathrm{OE}$ and provided insight into the mechanisms that underlie neurodevelopment.

\section{MATERIALS AND METHODS}

Tissue preparation. CD 1 mouse embryos of embryonic days 12-16 (E12E16) (as determined by a timed pregnancy, with E0.5 designated as the morning after an evening mating) and postnatal day (PD) 1 animals were fixed by immersion in freshly prepared $4 \%$ paraformaldehyde in PBS or Bouin's fixative (Sigma, St. Louis, MO) overnight at $4^{\circ} \mathrm{C}$. Fixed embryos were washed in $1 \times$ PBS and then in saline for $30 \mathrm{~min}$ each at $4^{\circ} \mathrm{C}$, dehydrated through a graded series of ETOH washes, cleared in xylenes, and embedded in paraffin. Tissue sections $(8-10 \mu \mathrm{m})$ were collected on untreated Superfrost/Plus slides (Fisher, Pittsburgh, PA), heated at $56^{\circ} \mathrm{C}$ for $1 \mathrm{hr}$, and stored at $4^{\circ} \mathrm{C}$. Slides of E8, E10, and E11 National Institutes of Health Swiss mice embryos were purchased (Novagen, Madison, WI). Adult mice were perfused with ice-cold PBS followed by either freshly prepared 4\% paraformaldehyde in PBS or Bouin's solution. Tissues of interest were removed and post-fixed in fresh fixative for $2 \mathrm{hr}$ at $4^{\circ} \mathrm{C}$. Adult sections were prepared as described for embryos.

Anti-peptide antibody generation. To generate specific antisera to Pax-6 and Olf-1, peptides corresponding to the $17 \mathrm{C}$-terminal residues of the mouse Pax-6 protein $\left(\mathrm{H}_{2} \mathrm{~N}\right.$-QVPGSEPDMSQYWPRLQ-COOH) and the 16 C-terminal residues of the Olf-1 protein $\left(\mathrm{H}_{2} \mathrm{~N}\right.$ NGNSLQAISGMIVPPM-COOH) were synthesized, coupled to bovine serum albumin (BSA) using glutaraldehyde, and injected into rabbits to generate polyclonal antisera. By Western blot analysis, the crude antiserum detected protein products of the predicted size from lysates containing recombinant protein. The Pax- 6 antisera were purified on an affinity column prepared by linking the Pax-6 peptide to Affi-Gel 10 support according to the manufacturer's instructions (Bio-Rad, Melville, NY). Crude serum was passed over a peptide affinity column, and the matrix was washed with 20 bed volumes of $10 \mathrm{~mm}$ Tris, $\mathrm{pH} 7.5$, followed

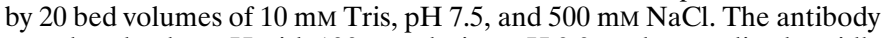
was eluted at low $\mathrm{pH}$ with $100 \mathrm{~mm}$ glycine, $\mathrm{pH} 3.0$, and neutralized rapidly with $1 \mathrm{~m}$ Tris, $\mathrm{pH}$ 8.0. Antisera to Olf-1 were purified over a Protein A Sepharose column according to manufacturer's instructions. Material eluted from each of the columns was stabilized with BSA (100 ug/ml), and aliquots were stored at $-80^{\circ} \mathrm{C}$.

Western blot analysis of Pax-6 protein. Total cellular protein was prepared from tissues of adult C57BL/6 mice by homogenization in $2 \times$ SDS sample buffer using a polytron. After an equal volume of water was added to each sample, equivalent amounts of protein were fractionated on a $12 \%$ polyacrylamide gel under reducing conditions and transferred to a nitrocellulose membrane for $24 \mathrm{hr}$ at $100 \mathrm{~mA}$. The filter was incubated in Tris-buffered saline (TBS) containing 5\% nonfat dry milk to reduce nonspecific binding and incubated with affinity-purified Pax-6 antiserum $(1 / 200)$ for $16 \mathrm{hr}$ at $4^{\circ} \mathrm{C}$; immunoreactivity was visualized with HRPconjugated anti-rabbit Ig and enhanced chemiluminescence (Amersham, Arlington Heights, IL).

Immunohistochemistry. All steps were carried out at room temperature except where noted otherwise. Sections were deparaffinized in Hemo-De (Fisher) twice for $5 \mathrm{~min}$ each, rehydrated using a graded series of ETOH washes, and washed in PBS for $15 \mathrm{~min}$. To optimize antigenicity in tissue that had been perfused or immersion-fixed in paraformaldehyde, the slides were placed in a dish of water ( $\sim 1-1.5$ inches on top of the slides), section-side up, and microwaved on a setting of high for $15 \mathrm{~min}$, allowed to cool to room temperature, post-fixed in Bouin's solution for $15 \mathrm{~min}$, and washed with several changes of PBS. Tissue sections were placed in a humidified chamber, blocked in $10 \%$ normal goat serum (NGS) in PBS for $15 \mathrm{~min}$, and incubated with primary antiserum in 2\% NGS in PBS for $60 \mathrm{~min}$ [1:100 dilution for IgG-purified anti-Olf-1 Ab, 1:30 for affinitypurified anti-Pax-6 Ab, and a 1:2000 dilution for polyclonal anti-NCAM (Chemicon, Temecula, CA)]. The sections were washed several times in PBS, 5 min each, treated for endogenous peroxidases with 3\% hydrogen peroxide in water for $15 \mathrm{~min}$, and washed again in PBS. Sections were incubated with biotinylated anti-rabbit Ig and avidin-biotin-horseradish

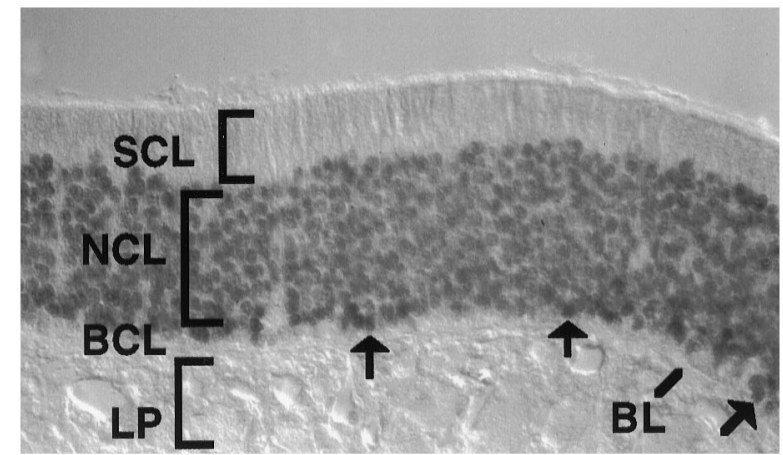

Figure 1. Expression of Olf-1 in adult olfactory epithelium. Olf-1 protein was localized to the nuclei of olfactory neurons of an adult mouse using an anti-Olf-1 peptide antibody. Immunoreactive GBC nuclei are indicated (arrows), as are the locations of sustentacular cell layer $(S C L)$, neuronal cell layer $(N C L)$, basal cell layer $(B C L)$, basal lamina $(B L)$, and lamina propria $(L P)$.

peroxidase complex (Vectastain Elite ABC kit; Vector Labs, Burlingame, CA). Immunoreactivity was visualized with diaminobenzidine, Vector SG, or Vector VIP chromagens. Stained sections were mounted and coverslipped using Aqua-Poly/Mount (Polysciences, Warrington, PA).

\section{RESULTS}

\section{Embryonic expression pattern of Olf-1 in postmitotic cells of the CNS and peripheral nervous system}

To examine the expression pattern of Olf-1 during development, an antibody was generated to a peptide corresponding to the C-terminal 16 amino acids of the rat Olf-1 protein. The IgGpurified, anti-Olf-1 peptide antiserum (JH1132.5) was immunoreactive specifically with the nuclei of olfactory neurons and a subset of basal cells in the pseudostratified OE of the adult mouse (Fig. 1). Adjacent sections of adult mouse OE treated with either preimmune serum or with anti-Olf-1 antibody preincubated with the peptide showed no staining. The same pattern of immunostaining in adult rat $\mathrm{OE}$ was observed using a polyclonal antiserum generated to an Olf-1/GST fusion protein (Wang and Reed, 1993). Further characterization by Western blot analysis showed that the Olf- 1 anti-peptide antibody specifically recognized a band of $\sim 69 \mathrm{kDa}$ in HEK-293 cells transfected with the Olf-1 cDNA under the control of the CMV promoter (data not shown).

Olf-1 expression in mouse embryos was first observed in the $\mathrm{CNS}$ at E11 in the $\mathrm{OE}$ and in the anlage of the vomeronasal gland (VNO) in the olfactory pit (see Fig. $6 A$ ), a time when neuronal cell bodies within the epithelium begin to extend dendrites and axons (Cuschieri and Bannister, 1975a,b; Pellier et al., 1994). Cells in proximity to the olfactory axonal projection to the presumptive olfactory bulb were also Olf-1 positive (see Fig. $6 A$ ) and may represent luteinizing hormone-releasing hormone (LNRH) neurons known to migrate from the olfactory placode to the hypothalamus at this time. A second site of strong Olf-1 staining at E11 was in a subset of presumptive sensory neurons in the dorsal root ganglion (DRG), at a time coincident with onset of neurogenesis in this tissue (Altman and Bayer, 1984) (data not shown). Faint staining was detected throughout the brain at this time (see below). No signal was detected in the embryo before E11, even in the olfactory pit and the cellular condensation of DRGs. Sections incubated with preimmune serum failed to stain.

A wider distribution of Olf-1 expression was detected by E12 in the mouse. Transverse sections revealed strong Olf-1 staining in all of the main subdivisions of the embryonic brain (Fig. 2). Olf-1 


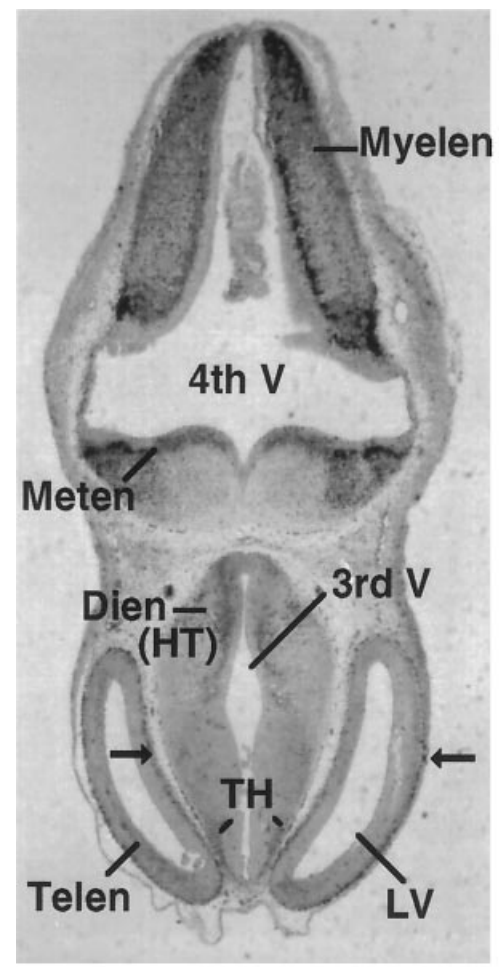

A

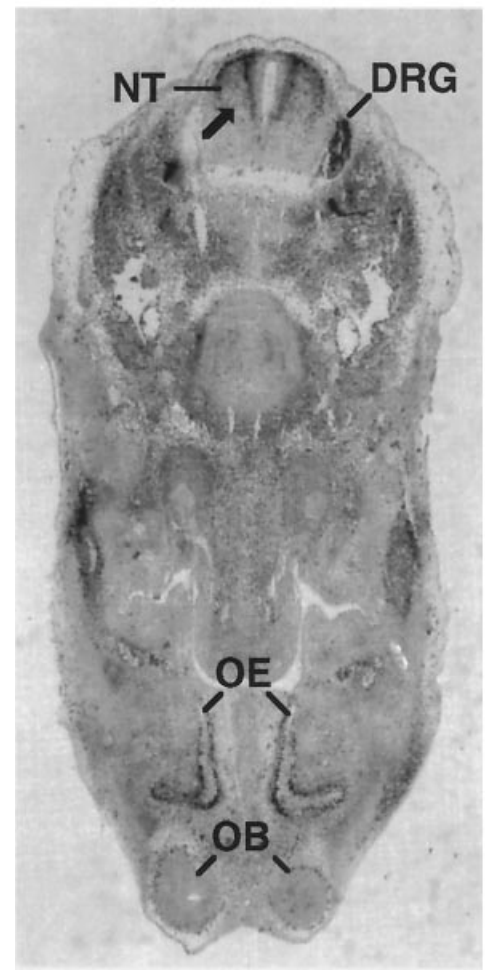

D

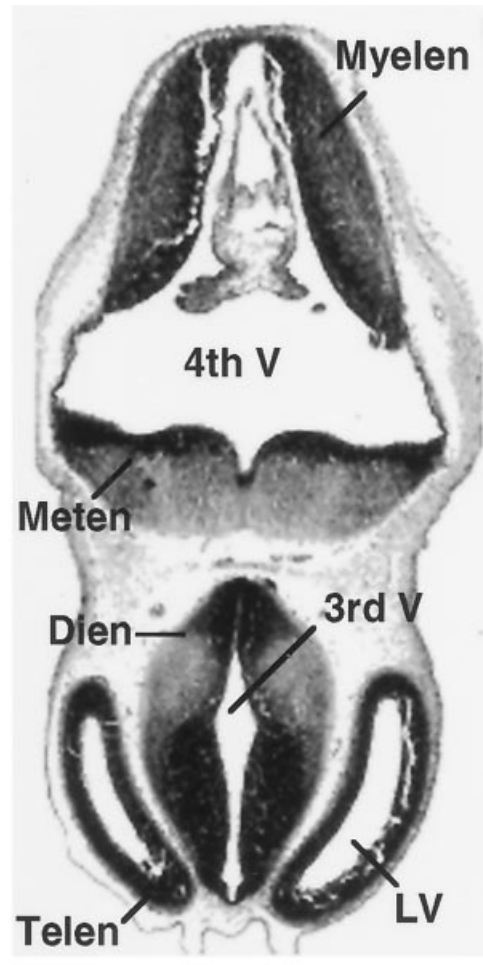

B

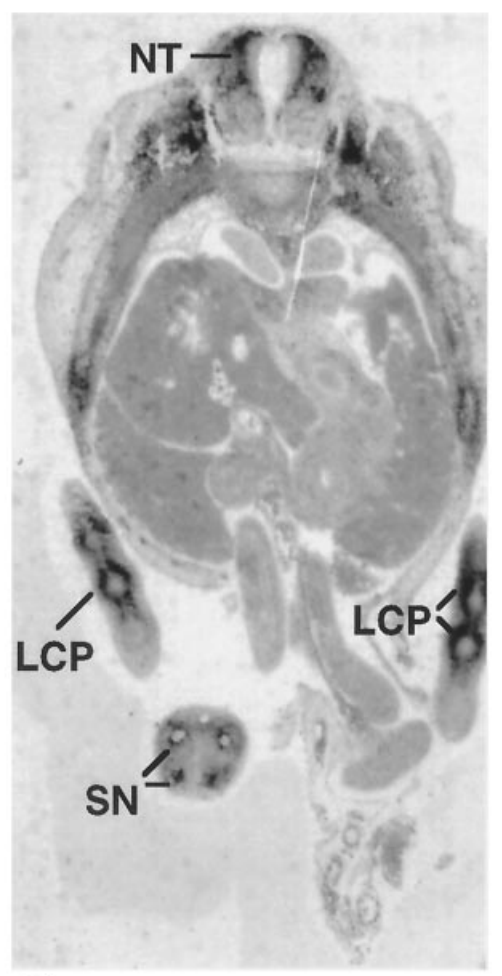

E

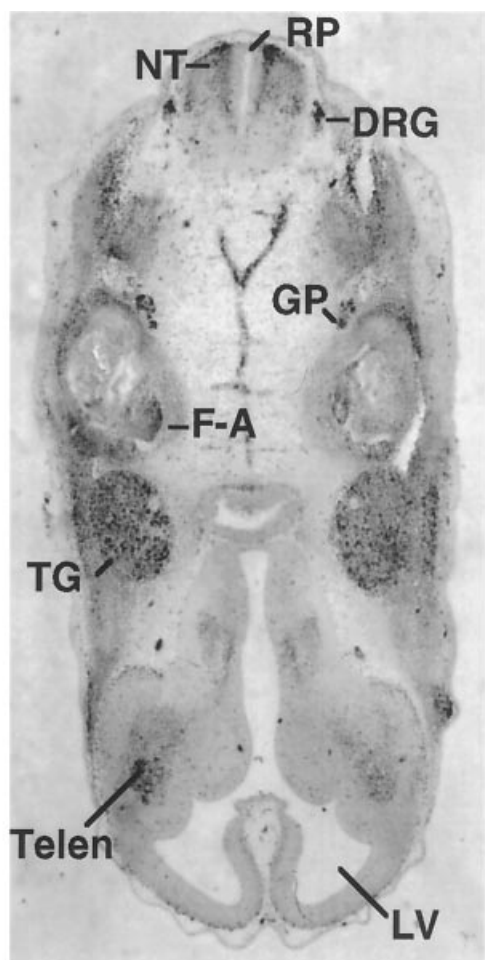

C

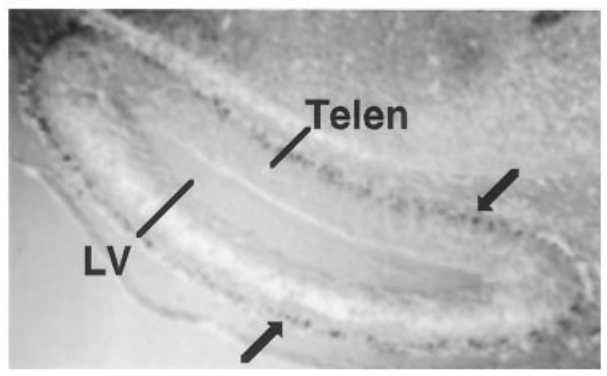

F

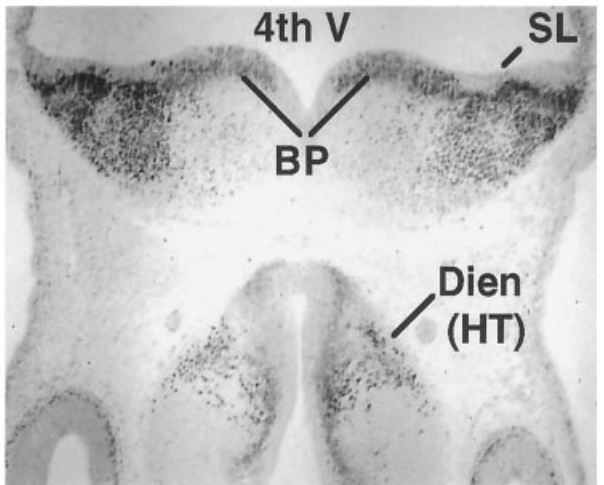

G

Figure 2. E12 expression of Olf-1 in the mouse. Low-magnification views of transverse sections (dorsal side at top) of an E12 mouse stained with the Olf-1 antibody ( $A$, most anterior; $C-E$, most posterior; $B$, hematoxylin/eosin). The cell-dense, ventricular layer in the major brain vesicles is denoted by the strong black staining in $B$. Cells outside of this layer are stained a gray color $(B)$. Olf- 1 immunoreactivity in the mantle layer of the telencephalon is indicated by arrows in $A$ and $F . F$ and $G$ are higher-magnification views of the section in $A$. Neural structures are indicated as follows: telencephalon (Telen), diencephalon (Dien), metencephalon (Meten), myelencephalon (Myelen), basal plate (BP), neural tube (NT), trigeminal ganglion (TG), facioacoustic ganglion complex $(F-A)$, glossopharyngeal nerve $(G P)$, dorsal root ganglia $(D R G)$, olfactory epithelium $(O E)$, olfactory bulb $(O B)$, segmental nerves $(S N)$, fourth ventricle (4th $V)$, third ventricle $(3 r d V)$, lateral ventricle $(L V)$, roof plate $(R P)$, and sulcus limitans $(S L)$. Olf-1-positive cells were also detected in the precartilage primordium of the limbs $(L C P)$. 
immunoreactivity was observed in a thin layer of cells located in the telencephalon (Fig. 2A,F). The Olf-1 signal coincides with the postmitotic cells adjacent to the proliferative, ventricular layer denoted by the cellular dense region of deep purple (black in Fig. $2 B$ ) after staining with hematoxylin/eosin. No Olf-1-positive immunoreactivity was observed in the proliferative, ventricular zone adjacent to the lateral ventricles. A discrete pattern of Olf-1 expression was observed in the diencephalon in regions of future thalamus and hypothalamus (Fig. $2 A, G$ ). Olf-1 was localized to several regions adjacent to the fourth ventricle, including the alar plate of the myelencephalon and the alar lamina and basal plate of the metencephalon (Fig. $2 A$ ). Differential staining with hematoxylin/eosin confirmed that Olf-1 staining was absent from cells residing in the proliferative, ventricular layer adjacent to all ventricles (Sidman et al., 1959; Bulfone et al., 1995), with the exception of cells in the basal plate of the metencephalon (Fig. $2 B$ ). We conclude that strong Olf-1 expression is restricted to postmitotic cells immediately adjacent to, but not including, the proliferative, ventricular layer in the E12 telencephalon, diencephalon, metencephalon, and mylencephalon.

Olf-1 expression was particularly abundant in a number of structures that mediate sensory activity in the adult. At a level caudal to the hindbrain, Olf-1 was expressed in the dorsal (alar plate) but not the ventral (basal plate) region of the neural tube at E12 (Fig. 2C-E). Olf-1 staining stopped abruptly at a point corresponding to the ventral border of the alar plate and was absent from the roof plate and cells immediately adjacent to the central canal in the ventricular layer of the neural tube (Sauer, 1935; Nornes and Carry, 1978). Olf-1 expression could be detected at E12 in the sensory neuron-containing trigeminal ganglia, facioacoustic ganglion complex, glossopharyngeal nerve, and additional DRGs adjacent to the spinal cord (Fig. 2C). Sensory neurons within the DRGs continued to express Olf-1 at E12 (Fig. $2 D$ ). Intense staining was observed in the developing neural layer of the optic cup (data not shown), the margins of the future olfactory bulbs, and the OE (Fig. 2D). Finally, a transverse section through the abdominal region of the E12 embryo showed Olf-1 immunoreactivity in the four segmental nerves of the tail and in the precartilage primordium of the limbs (Fig. 2E).

At midgestation, when the brain is undergoing massive proliferation and differentiation (Angevine and Sidman, 1961; Angevine, 1970; Altman and Bayer, 1985), intense Olf-1 staining was observed in the telencephalon in a thin layer of cells within the cerebral cortex and more diffusely in the primordium of the corpus striatum (Fig. $3 A, B$ ). Olf-1 was also detected in the maturing olfactory bulb, which has begun to receive axons from the OE (Fig. 3B). Discrete Olf-1 immunoreactivity was seen in the diencephalon where hypothalamus and thalamus are developing at E14 (Fig. 3A,B). Neuronal cells forming specific thalamic nuclei arise over a period of 3-4 d between E10 and E15 (Altman and Bayer, 1979, 1988). Olf-1 expression was not homogeneous in the diencephalon and so may preferentially label cells comprising specific thalamic and hypothalamic nuclei. Intense Olf-1 staining was observed at E14 in the rhombencephalon (Fig. 3A-C), including the future pons and medulla oblongata, concomitant with a marked degree of differentiation in these hindbrain primordia between E13.5 and E15 (Altman and Bayer, 1985; Kaufman, 1992). The staining detected in the liver (Fig. 3E) was not nuclear and was also observed with preimmune serum.

Highest levels of Olf-1 protein expression in the E14 embryo were restricted to sensory structures. In particular, the olfactory turbinates, the VNO, and the neural retina (Fig. 3C,D) stained intensely with the antibody. Olf- 1 expression was also observed in the primordia of follicles of vibrissae, or whiskers, the principal tactile receptors on the face. Olf-1 expression was first observed in components of the inner ear at this time (Fig. 3D,F). In the trigeminal ganglion, the majority of neurons expressed Olf-1, although the most intense staining occurred at the periphery (Fig. $3 C, G)$. We did not detect Olf-1 expression in any other tissues at E14.

The spatial pattern of Olf-1 expression was retained at E16 in the mouse embryo (data not shown). No additional sites of Olf-1 immunoreactivity were detected. By PD1, Olf-1 immunostaining was dramatically reduced or absent in all embryonic locations except the spinal cord (see below) and in sites that in the adult continue to express Olf-1, including the OE, VNO, and retina.

\section{Olf-1 expression in sensory neurons of the spinal cord and DRGs of the embryonic mouse}

Olf-1 was expressed transiently in a spatially restricted pattern along the dorsoventral axis of the neural tube. At E12, robust Olf-1 staining was observed in cells of the dorsal neural tube. In particular, cells within the dorsal horns, the sensory neurons derived from the alar plate, exhibited intense Olf- 1 immunoreactivity, whereas Olf-1 protein was conspicuously absent from the roof plate cells (Fig. 4A). Olf-1 protein was not detected in the proliferative, ventricular layer of the neural tube, but rather was restricted to nuclei of postmitotic cells in the mantle layer of the neural tube, as assessed by hematoxylin/eosin staining (data not shown). Interestingly, the onset of Olf-1 expression at E12 coincided with the birth of dorsal horn neurons at E11.5-E13.5 (Nornes and Carry, 1978). A few cells were Olf-1-positive in the intermediate zone and in the ventral horns. By PD1, fewer cells were positive for Olf-1, and their location was further restricted to the outermost zones of the dorsal horn (Fig. 4B). A similar pattern of Olf-1 immunostaining was seen along the rostrocaudal axis of the spinal cord.

An early site of Olf-1 expression in the developing embryo was the DRGs, composed of sensory neurons that transduce somatosensory information. At later embryonic times, the DRGs continued to stain intensely with the Olf- 1 antibody (Fig. $4 C-E$ ). The expression of Olf-1 in DRGs was confirmed by in situ hybridization with an ${ }^{35} \mathrm{~S}$-labeled Olf-1 probe on adjacent sections (data not shown). Expression of Olf-1 protein in the DRG was not uniform. Neurons of different cell diameters are specifically associated with particular sensory modalities. Interestingly, Olf-1 was expressed in smaller-diameter cells that convey pain and thermal sensation, rather than the larger-diameter ganglion cells of the DRG that mediate discriminatory touch and propriosensation.

\section{Expression pattern of Olf-1 in the mouse retina and OE correlates positively with neuronal differentiation}

Staining with the Olf-1 antibody was found in the neural retina at all ages examined, but the distribution of the antigen showed dramatic changes during development. The onset of Olf- 1 expression at E12 was restricted to cells in the central region of the inner layer (IL) of the neural retina, adjacent to the optic nerve (Fig. $5 A$ ). These represent the first cells in the neural retina to exit the cell cycle (Young, 1985). A greater number of cells in the IL, extending from this central region toward the peripheral margins of the retina, were Olf-1 positive by E14 (Fig. 5B). By E16, Olf-1 protein was detected in most if not all cells of the IL (Fig. $5 C$ ). Olf-1 staining was not observed in the outer layer (OL) of the neural retina in cells corresponding to the proliferative, ventricu- 


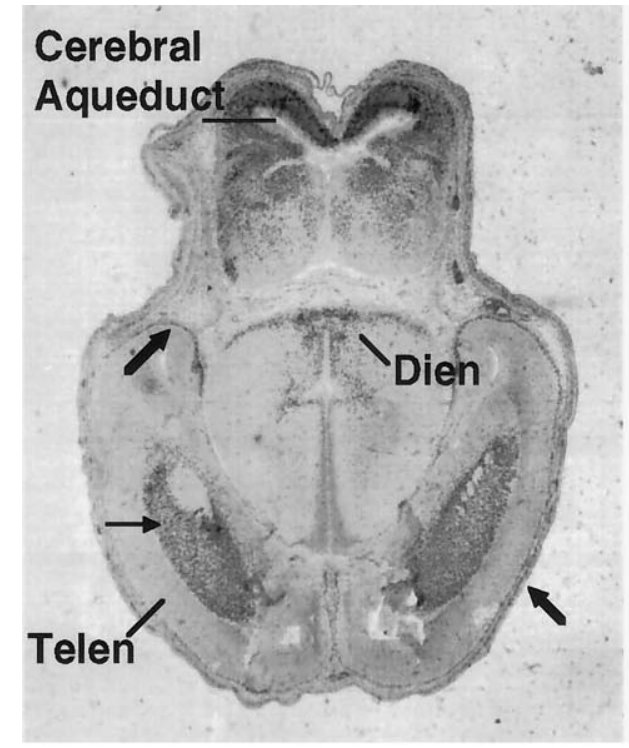

A

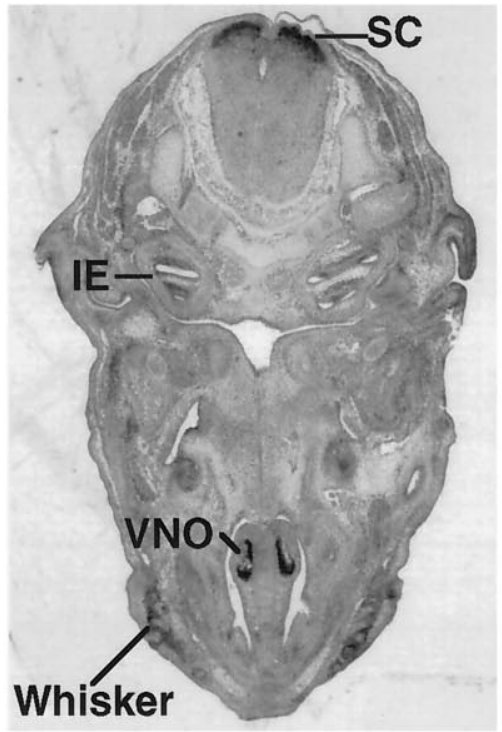

D

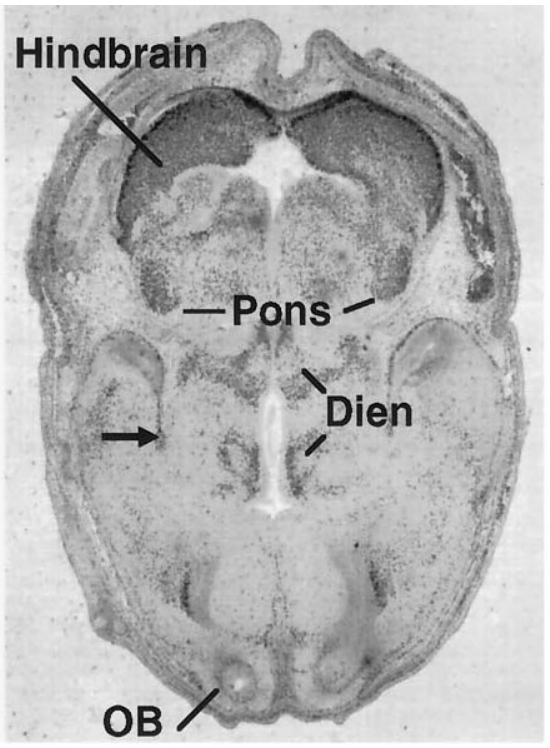

B

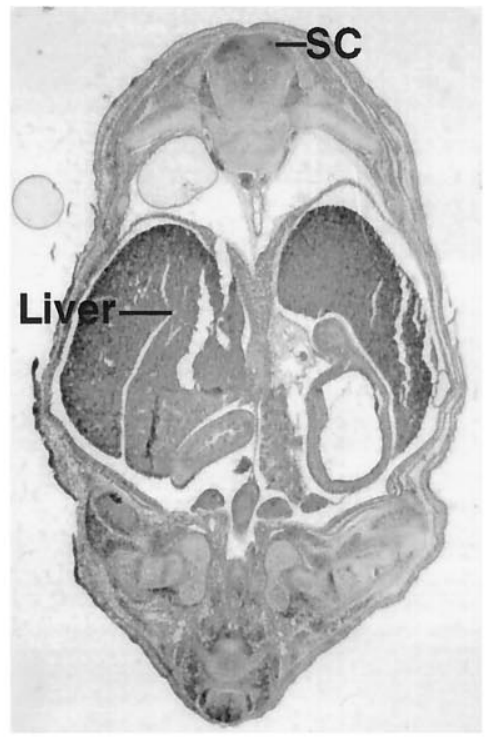

E

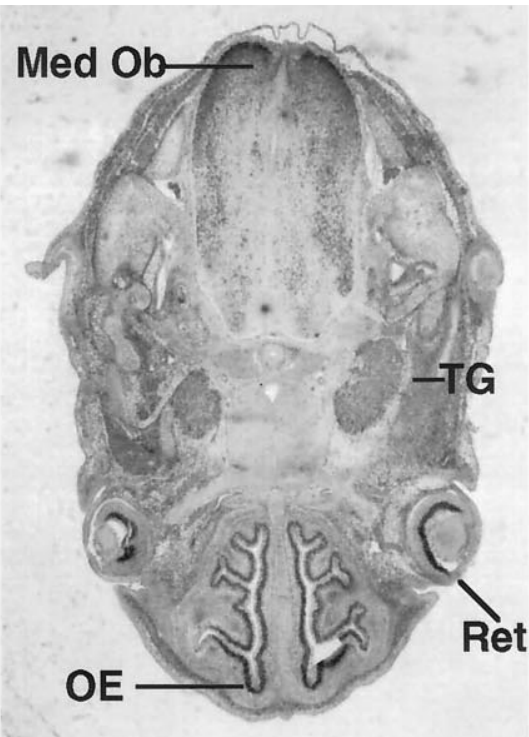

C

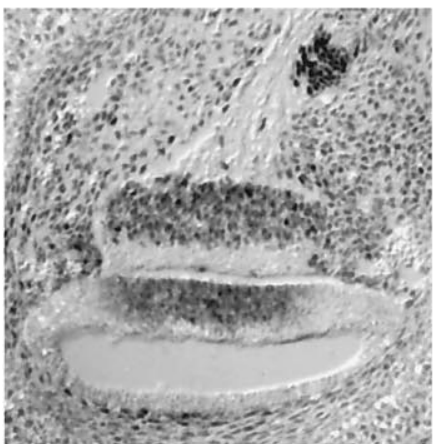

F

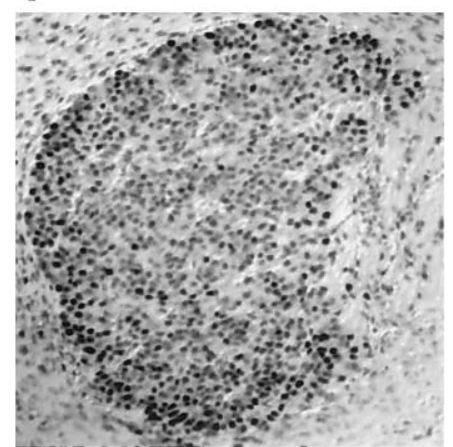

G

Figure 3. E14 expression of Olf-1 in the mouse. Transverse sections of an E14 mouse embryo immunostained with the Olf-1 antibody $(A-G)$. In the telencephalon (Telen), Olf-1 staining was detected in the cortex (bold arrows in $A$ and $B$ ) and in the striatum (small arrow in $A$ ). Discrete Olf-1 immunoreactivity is observed $(A, B)$ in the diencephalon (Dien), in broad areas of the hindbrain including the pons (Pons) and medulla oblongata (Med $O b)$, and in sensory structures including the retina (Ret), olfactory epithelium $(O E)$, olfactory bulb $(O B)$, vomeronasal gland $(V N O)$, whisker primordia (Whisker), and dorsal spinal cord $(S C) . F$ and $G$ are high-magnification views of inner ear $(I E)$ and trigeminal ganglion $(T G)$, respectively.

lar cells common to the rest of the neural tube. Neuroretinal differentiation proceeds in a progressive fashion in two directions: laterally, from the optic nerve toward the peripheral margins of the retina, and radially, from the IL (the layer closest to the lens) toward the OL of the neural retina. The pattern of retinal Olf- 1 protein reflects this progressive process of differentiation in both the radial and lateral directions (Sidman, 1970; Young, 1985). Olf-1-positive cells at PD1 were located in the ganglion cell layer
(GCL) and the developing inner nuclear layer (INuL) (Fig. 5D,E). In the adult mouse retina, we continued to detect Olf- 1 expression in a discrete population of cells (Fig. $5 F$ ) in the GCL and in a subset of cells located in the inner half of the INL, perhaps amacrine cells. Olf-1 protein was not detected in the pigmented retina or in other parts of the developing or adult eye.

Expression in the OE is of particular interest, because differentiation continues in this tissue throughout embryonic and adult 


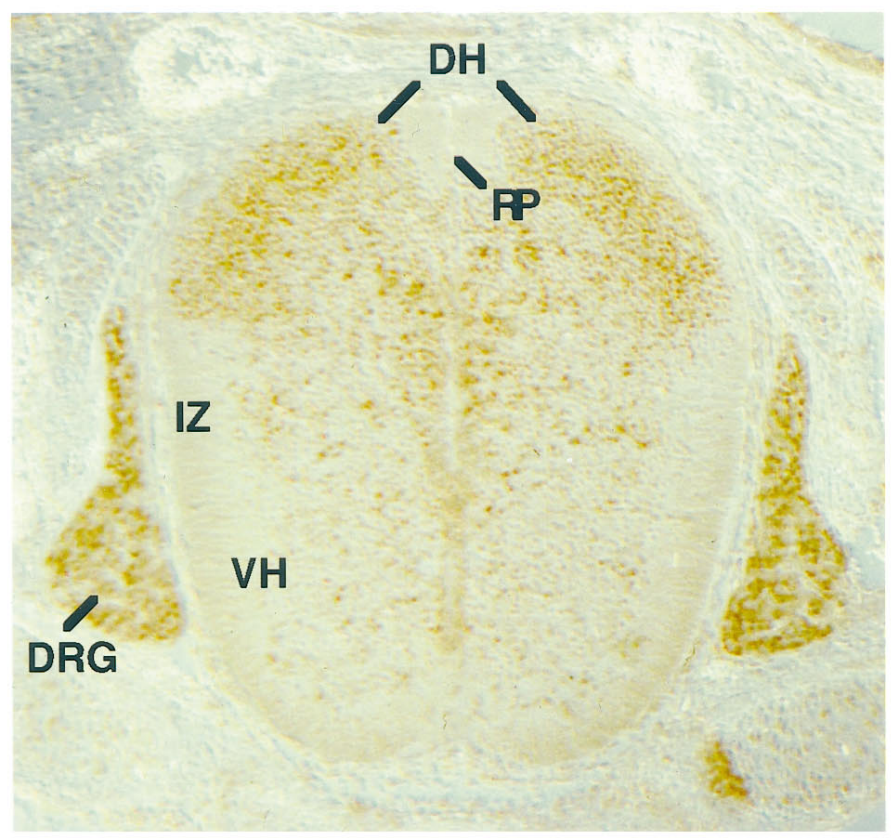

A
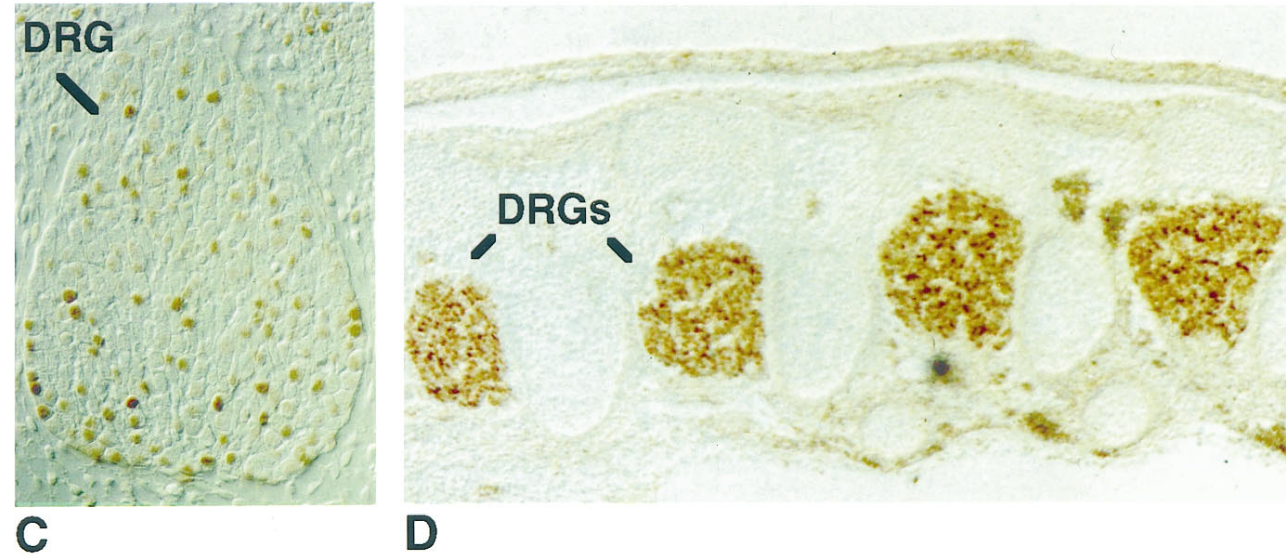

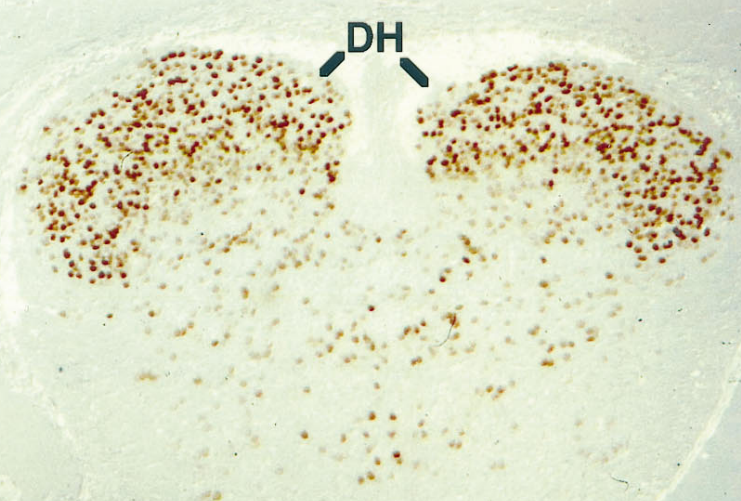

B

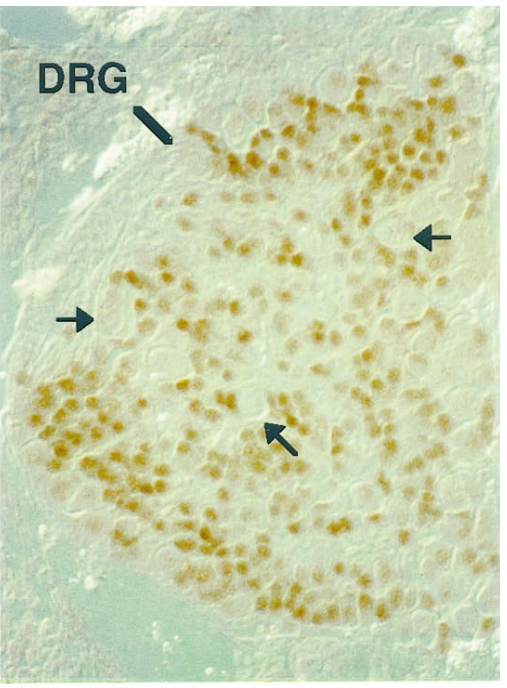

E

Figure 4. Embryonic expression of Olf-1 protein in the spinal cord and DRG. Transverse sections (dorsal side at top) of the spinal cord in an E12 $(A)$ and PD1 $(B)$ mouse stained with the Olf-1 antibody. Intense Olf-1 staining was detected predominantly in sensory neurons of the dorsal horns $(D H)$, whereas only a few cells in the intermediate zone $(I Z)$ and ventral horns $(V H)$ were Olf-1-positive. No Olf-1 staining was observed in the roof plate $(R P)$. Sagittal views of the dorsal root ganglia $(D R G)$ revealed Olf-1 expression at E11 $(C)$, E12 $(A)$, E14 $(D)$, and E16 $(E)$. $C$ and $E$ are high-magnification views.

life. An olfactory turbinate at E12 showed Olf-1 immunostaining throughout the epithelium (Fig. 6B). A higher magnification of the epithelium revealed nuclear localization of the Olf-1 protein (Fig. 6C). By E14, when the turbinates become more convoluted and the pseudostratification of the OE is established, Olf-1 expression was confined to the lower two thirds of the epithelium, corresponding to the neuronal cell layer (Fig. $6 D, E$ ). The pattern of Olf-1 expression at E16 is similar to that observed at E14 (Fig. $6 F, G)$, and in particular, Olf-1 positive cells lying close to the basement membrane, possibly basal cells, were evident.

\section{Pax-6 expression in non-neuronal components of the OE in the embryonic and adult mouse}

Antibodies to Pax-6 were generated, and their specificity was characterized by Western blot analysis. In agreement with the localization of Pax-6 mRNA determined by in situ hybridization (Walther and Gruss, 1991), the Pax-6 antibody detected two closely migrating bands of $\sim 50 \mathrm{kDa}$ on SDS polyacrylamide gels of tissue extracts from adult brain, olfactory bulb, eye, and olfactory turbinates, but not in liver (Fig. 7). The protein doublet corresponds to the sizes predicted for alternative spliced variants of Pax-6 (Walther and Gruss, 1991), whereas additional immunoreactive bands of faster mobility were detected in brain, in olfactory bulb, and in eye and may reflect alternative Pax-6-derived proteins (Martin et al., 1992) or breakdown products.

In the eye, Pax-6 immunohistochemistry revealed nuclear localized protein in both neuronal and non-neuronal cells in a pattern consistent with the low resolution in situ hybridization studies of Walther and Gruss (1991). At E12, Pax-6 immunostaining was detected in the developing cornea and lens, which arise from a neuroectodermally derived placode. Both layers of the optic cup, which will form pigmented and neural retina, expressed Pax-6 protein (Fig. $8 A$ ). Pax-6 expression continued in the E16 cornea, 

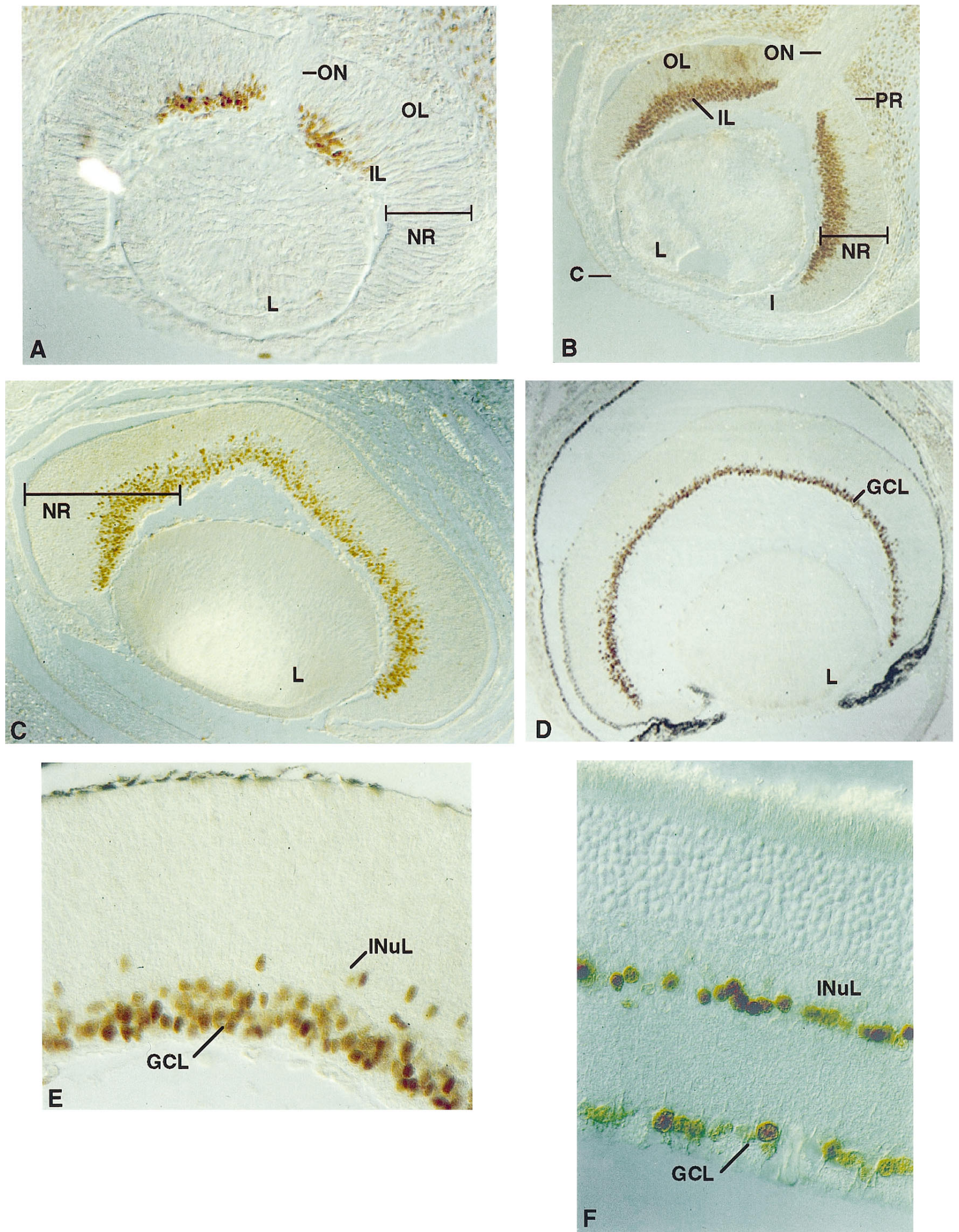

Figure 5. Localization of Olf-1 in the mouse retina. Olf-1 protein was detected by immunoperoxidase reactivity in the mouse retina at all ages examined, including E12 $(A)$, E14 $(B)$, E16 $(C)$, PD1 $(D, E)$, and adult $(F)$. Lens $(L)$ is at the bottom in $A-D$. Inner layer $(I L)$, outer layer $(O L)$, neural retina $(N R)$, optic nerve $(O N)$, iris $(I)$, cornea $(C)$, and pigmented retina $(P R)$ are indicated. The darkened PR in $D$ was also observed with preimmune serum. Olf-1 protein resided in cells of the ganglion cell layer $(G C L)(D)$, and a high-magnification view $(E, F)$ revealed a few Olf-1-positive cells in the inner nuclear layer $(I N u L)$. 

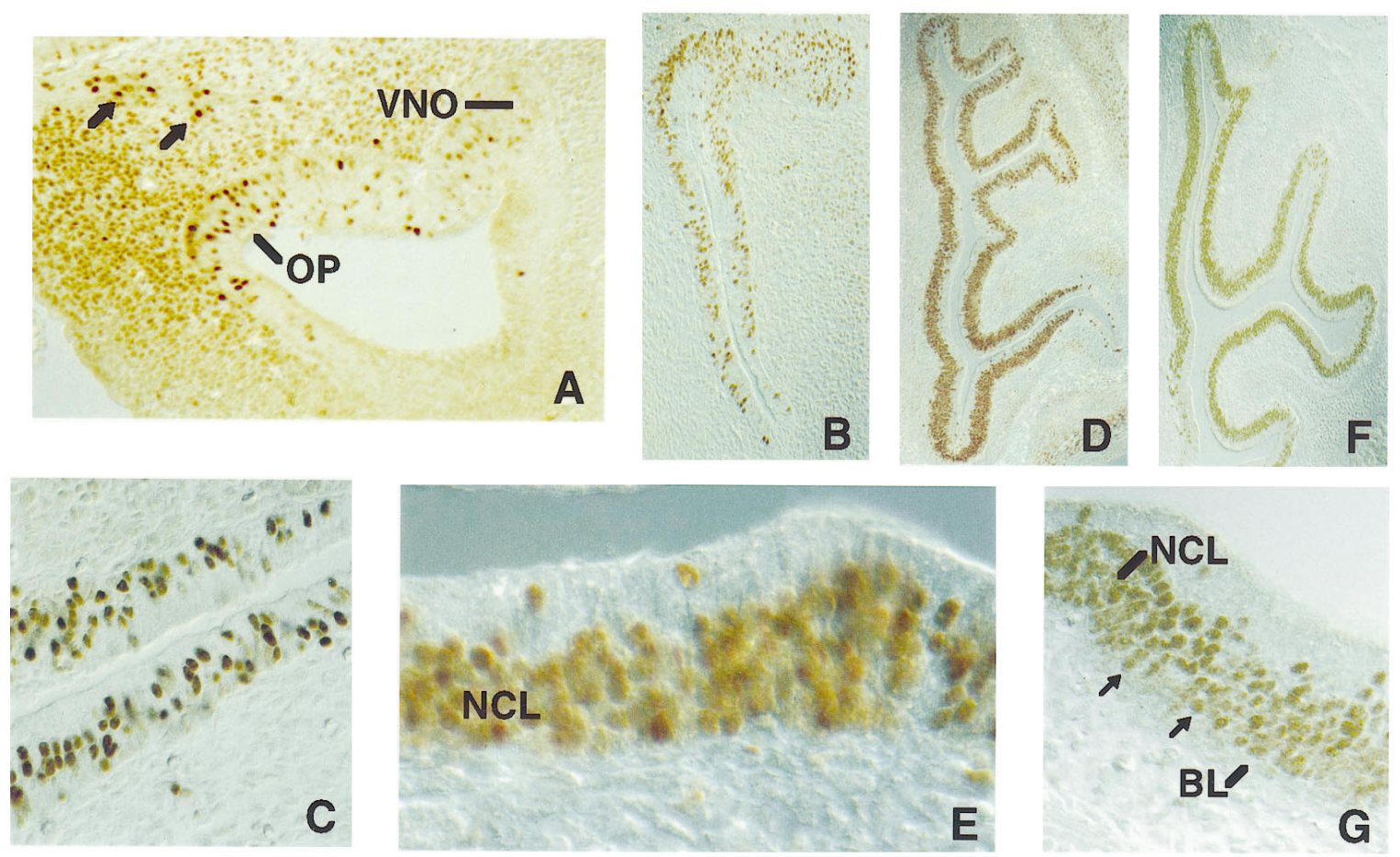

Figure 6. Embryonic expression of Olf-1 in the olfactory pit and epithelium. $A$, Expression of Olf-1 in the olfactory pit $(O P)$. Olf-1 protein was localized to the ventral portion of the unstratified neuroepithelium that lines the OP and in nuclei located in an invagination of the OP, representing the anlage of the vomeronasal organ $(V N O)$. Olf-1-positive nuclei adjacent to axonal projections from the olfactory nerve, possibly future LNRH-secreting neurons, are indicated with arrows. Low- $(B, D, F)$ and high-magnification views $(C, E, G)$ at E12 $(B, C)$, E14 $(D, E)$, and E16 $(F, G)$ revealed Olf-1 immunoreactivity in the neuronal cell layer $(N C L)$ and basal cells (indicated by arrows) near the basal lamina $(B L)$.

lens, and neural retina, although expression was not detected in the pigmented epithelium (Fig. 8B). The nonuniform Pax-6 immunostaining apparent at ED16 may reflect the developing laminar architecture of the retina. This pattern persists in the PD1 animal in all of the layers, even though considerable prenatal differentiation of retinal cell types has occurred (Turner and Cepko, 1987; Turner et al., 1990) (data not shown). Pax-6 expression in the adult retina was restricted to a subset of cells in the INuL, perhaps amacrine cells, and in scattered nuclei in the GCL (Fig. $8 C$ ). We also observed Pax-6 immunoreactivity in the ciliary ganglia at PD1 (data not shown).

The cellular localization of Pax-6 in the OE in a section from PD1 mouse olfactory turbinate was revealed by immunostaining with the Pax- 6 antibody. There was intense reactivity in the nuclei of the sustentacular cells and a subset of basal cells in the epithelium (Fig. $8 D, E$ ) as well as in a small number of cells in the middle region of the epithelium. All of the staining was blocked when the Pax-6 antibody was incubated with an excess of the specific peptide. At E12, when pseudostratification of the epithelium has not yet been established (Cuschieri and Bannister, 1975a), Pax-6 immunostaining was seen in nuclei located throughout the OE, much like the pattern observed for Olf-1 staining at that day of embryogenesis (Fig. 8F). By E16, Pax-6 immunoreactivity was restricted to nuclei in the apical and basal regions of the epithelium (data not shown) in a pattern that is retained in the adult mouse (Fig. 8G). In addition to cells in the neuroepithelium, Pax-6 was also detected in cells of the Bowman's glands (Fig. 8G) and occasionally in stained arrays of cells extending from the Bowman's glands through the epithelium, perhaps duct cells of the glands that open into the lumen.

To assess whether the basal cells that are immunoreactive with the Pax-6 antibody represent GBCs and/or HBCs, we performed double immunohistochemistry with the Pax-6 antibody and an antibody to neural cellular adhesion molecule (NCAM), a marker for GBCs and neurons but not HBCs (Miragall et al., 1988; Caggiano et al., 1994). Immunostaining with the anti-NCAM antibody on PD1 OE revealed cell surface localization of NCAM in GBCs as well as on neuronal cell bodies, dendrites, and axons (Fig. 8H). Pax-6 immunoreactivity, visualized with a reddishpurple substrate followed by NCAM staining (blue-gray), revealed that cells stained for either Pax-6 or NCAM but not for both of the antigens (Fig. 8I). Interestingly, Pax-6 is restricted to the nonGBCs and may represent a novel marker for the horizontal class of basal cells. The ability of this procedure to detect doublelabeled cells was demonstrated by incubating first with anti-Olf-1 antibody and subsequently with the NCAM antibody. The plasma membrane and the dendritic processes of the cells with Olf-1 positive nuclei are outlined (Fig. $8 J$ ).

\section{DISCUSSION}

\section{Olf-1 in olfactory development}

The expression of Olf-1 protein, originally identified in adult olfactory neurons, is first observed at ED11 and continues through gestation into the mature animal, where it is detected in olfactory sensory neurons and some basal cells. The VNO system and the main olfactory organ are primarily responsible for the detection of pheromones and volatile odorants, respectively (Shipley and Smith, 1995). The similar expression pattern of Olf-1 in the VNO and the OE proper may reflect their common embryonic origins from the olfactory placode and/or continual replacement of neurons in both systems (Barber and Raisman, 1974; Costanzo and Graziadei, 1987). Consistent with the idea that Olf-1 is expressed 

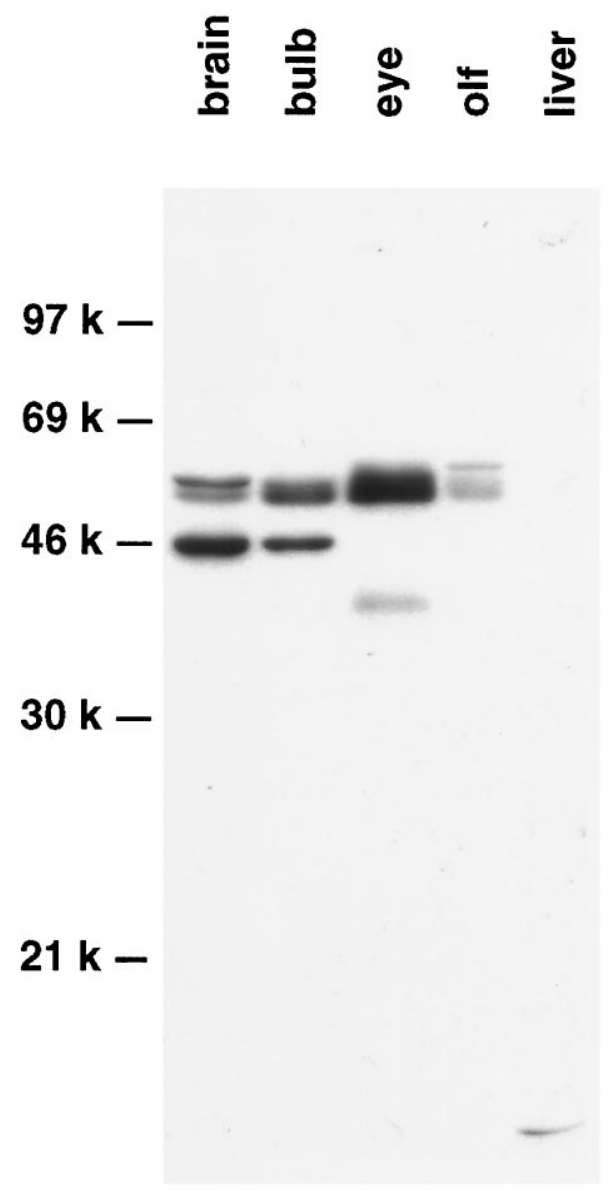

Figure 7. Western blot analysis of Pax-6 expression in the adult mouse. Tissue extracts from adult brain, olfactory bulb, eye, olfactory turbinates (olf), and liver were fractionated, and Pax-6 immunoreactive species were identified.

in olfactory placode derivatives is the finding that what may be LNRH neurons, which arise in the olfactory placode and migrate to the hypothalamus (Schwanzel-Fukuda and Pfaff, 1989), also seem to express Olf-1 protein. LNRH-positive cells migrate out of the olfactory pit at E11 coincident with the onset of Olf- 1 expression (Schwanzel-Fukuda and Pfaff, 1990).

Although transcription factors with restricted patterns of expression in the adult usually act to regulate a panel of tissuespecific genes, the same factors may have different roles during development, as has been shown for the distal-less-2 and fushi tarazu gene products (Price et al., 1991; Turner et al., 1994). The onset of Olf-1 expression at midgestation comes after the formation of the olfactory placode and subsequent invagination of the olfactory pit, making it unlikely that Olf-1 is involved in neuronal determination. The number of mitotic figures in the olfactory pit decreases at E11, and the epithelial cells begin to extend apical processes resembling dendrites to the apical surface and axon-like processes to the base of the epithelium (Smart, 1971; Cuschieri and Bannister, 1975a,b). In light of the finding that Olf-1 is turned on in the OE when neuronal precursors are leaving the cell cycle and beginning to differentiate, we propose that Olf- 1 plays a role in olfactory neuronal differentiation during embryogenesis as well as in the adult olfactory neurons. In other systems, factors with similar roles in neural development include T-Brain-1 (Bulfone et al., 1995) and Brn 3.2 (Turner et al., 1994). As an olfactory neuron matures, either later in gestation or during replacement in the adult epithelium, Olf-1 may function to activate transcription of olfactory neuron-specific genes, thereby regulating a specific cell phenotype (Treacy et al., 1991). An Olf-1 binding site has been identified in at least six olfactory-enriched genes (Kudrycki et al., 1993; Wang et al., 1993) and seems to play a functional role in the expression of at least one of these genes (Kudrycki et al., 1993). Temporally, Olf-1 expression precedes the onset of expression of several olfactory-enriched genes in the embryo and remains expressed in the mature neuron (Margalit and Lancet, 1993), consistent with a role in the establishment and maintenance of the neuronal phenotype.

A transcription factor from mouse pre-B lymphocytes known as early B-cell factor (EBF), apparently identical to Olf-1 (Hagman et al., 1993) except for eight amino acids introduced by alternative splicing, has been identified by virtue of its binding to a canonical Olf- 1 site in the proximal promoter of the mb- 1 gene. When the EBF/Olf-1 gene was disrupted by homologous recombination, the homozygous mutant mice had defects in B-cell development, whereas the OE appeared normal (Lin and Grosschedl, 1995). Interestingly, we have been unable to detect Olf-1 immunoreactivity in embryonic and adult sites of B-cell production (data not shown). We have obtained evidence for additional Olf-1-related proteins in OE (S. Wong and R. Reed, unpublished observations) that may serve partially redundant functions and explain the absence of observable olfactory deficits. MyoD and Myf-5, basic helix-loop-helix (bHLH) proteins involved in differentiation of muscle, play a similar, functionally redundant role in that system (Rudnicki et al., 1993). We have used in situ hybridization as a stringent method to confirm that the immunohistochemical studies described here reflect the pattern of expression of the Olf-1 gene (data not shown). An understanding of the function of Olf-1 and other members of this transcription factor family in neuronal development will require the complete mapping of their patterns of expression.

Development of the olfactory neuron, like other specific cell types, involves the sequential activation and inactivation of a hierarchy of transcriptional regulators. The expression of Olf- 1 in postmitotic cells suggests that it lies downstream of transcription factors that play a role in the commitment of proliferating cells to the neuronal lineage. Mash-1, a bHLH protein expressed in undifferentiated cells of the nasal placode at E9.5 (Guillemot and Joyner, 1993), is required for normal olfactory neuron development, as shown by the massive reduction in the number of these neurons in a Mash-1 knockout mouse (Guillemot et al., 1993). Moreover, a small number of cells express Mash-1 in the adult epithelium (Calof, 1995) and may represent precursors to terminally differentiated olfactory neurons in the adult. Our observation that Olf- 1 expression appears in differentiating neuronal cells, combined with the findings above, suggests that Olf- 1 may be a downstream target of Mash-1. A recently described bHLH gene, NeuroD, is expressed transiently in the CNS and peripheral nervous system (PNS), including the olfactory placode, and has been implicated in several steps of neural development (Lee et al., 1995). The role of NeuroD in olfactory neuron development, and its potential relationship with Olf-1, requires further study.

\section{Widespread Olf-1 expression in nervous tissue of the developing embryo}

The studies described here reveal that Olf- 1 is specifically associated with subsets of postproliferative neurons throughout the developing nervous system. The transient nature of its expression 


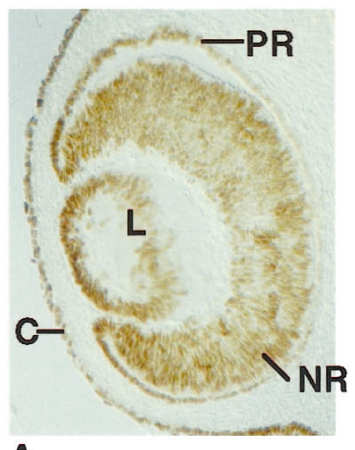

A

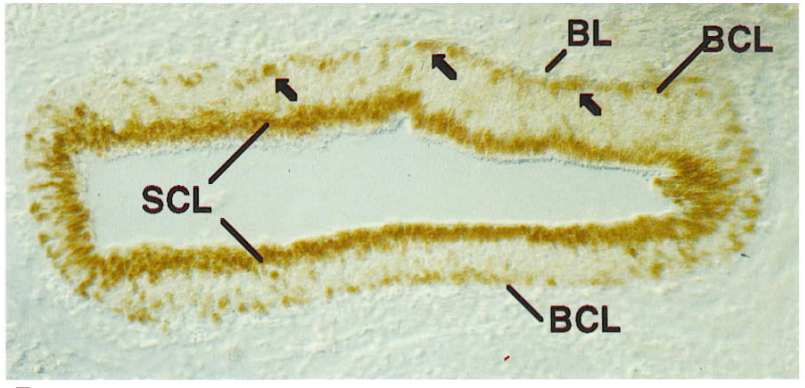

D

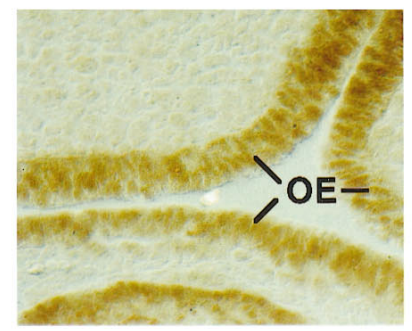

F

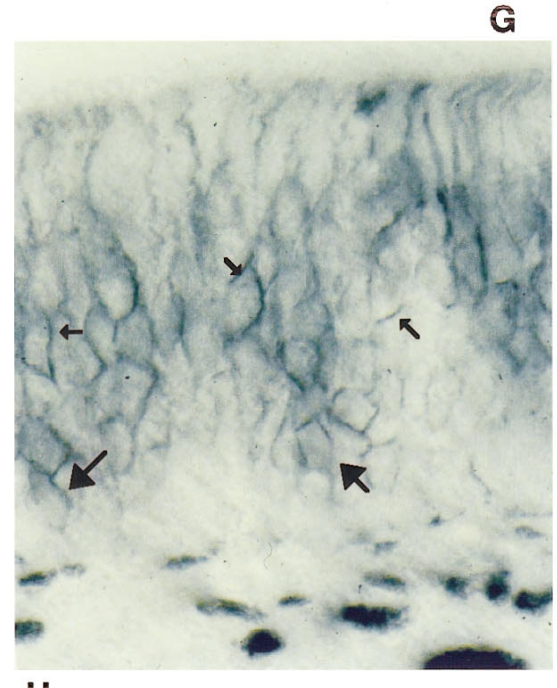

H

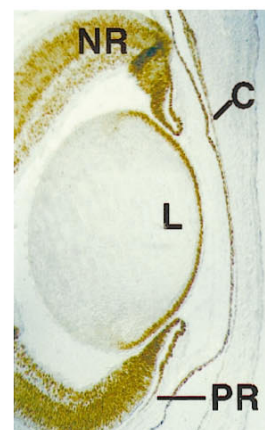

B

G
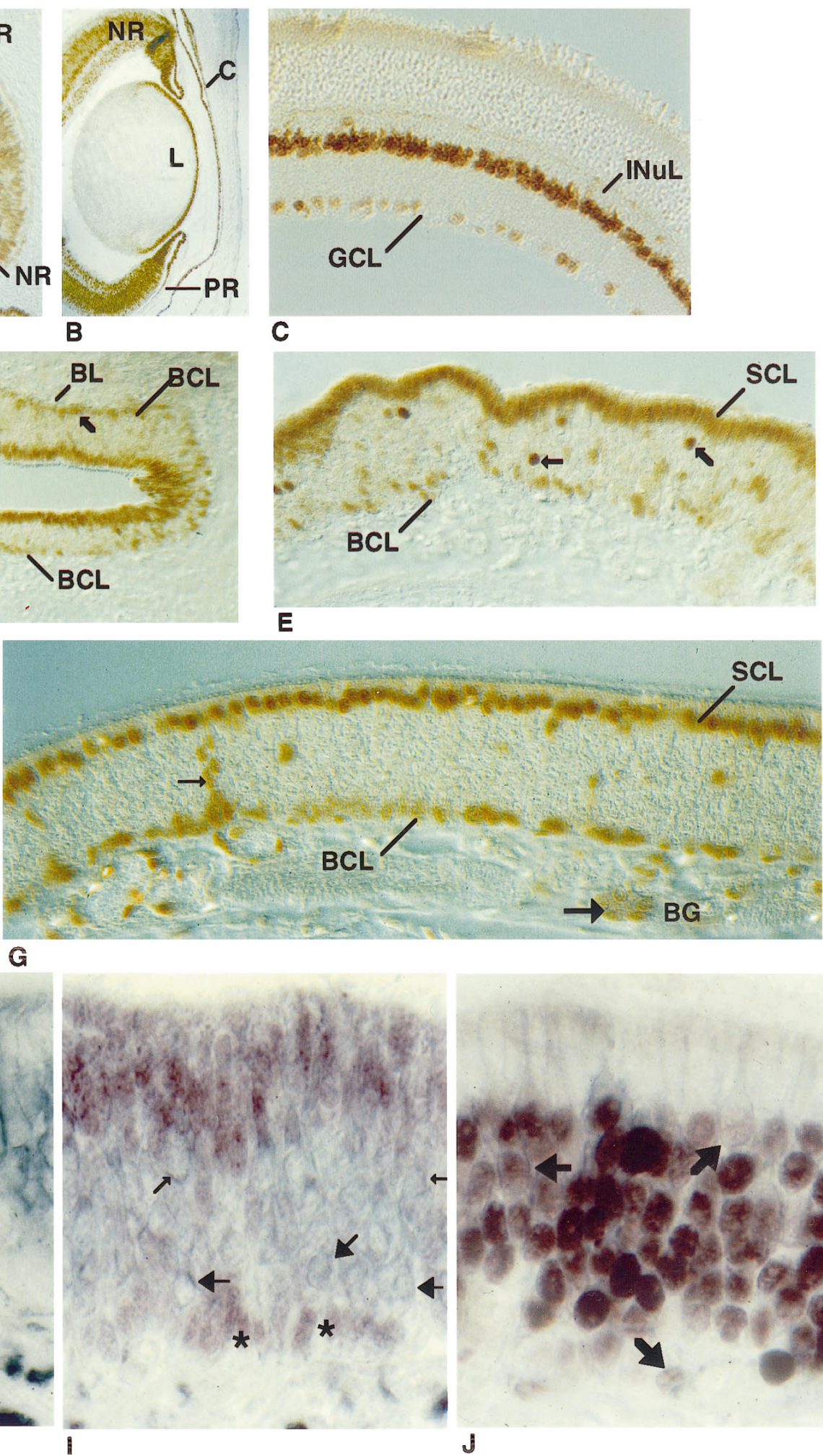

C

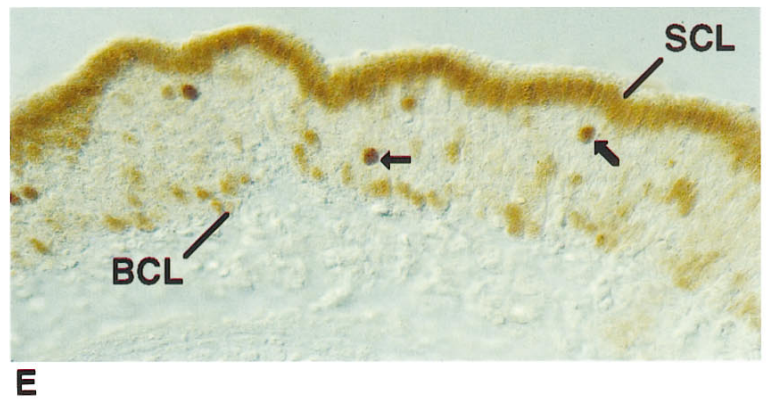

E

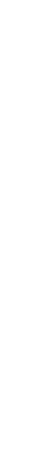


outside of the olfactory system and its sustained expression in adult olfactory neuronal tissue, which continues to proliferate throughout life, supports the hypothesis that Olf-1 functions in a more general role in neurogenesis. The unique spatial and temporal patterns of Olf- 1 expression in the embryo clearly suggest a role for the Olf-1 protein in neuronal development. Immunostaining and in situ hybridization (data not shown) revealed Olf-1 protein/mRNA in a subset of cells exclusively within the CNS and PNS. In general, Olf-1 is expressed transiently, beginning at E11 and continuing through late gestation; in the adult, it is extinguished in all tissues except the OE, VNO, and retina. The onset of Olf- 1 expression at a particular site within the nervous system precedes or coincides with overt differentiation at that site. For example, Olf-1 protein was detected at E11 in the DRGs shortly before peak production of the small-diameter cells on E12, whereas it was first observed at E12 in the spinal cord when sensory neurons, which are born from E11.5-E13.5, are commencing differentiation (Nornes and Carry, 1978). The spatial pattern of Olf-1 immunostaining, generally just outside the ventricular zone, suggests that Olf-1 is expressed in postmitotic cells. Neurons are born from dividing neuroblasts populating the ventricular zone surrounding the ventricle (lumen) of the CNS, and their progeny sequentially leave the mitotic cycle and migrate laterally into distinct locations to differentiate (Sidman et al., 1959; Angevine and Sidman, 1961). Therefore, both the timing and location of Olf-1 expression suggest a role for Olf- 1 in the postmitotic, neural cell that has commenced a course of differentiation. Olf- 1 joins a small group of factors that have been found selectively in postmitotic cells, including Brn-3.2, OTP, and T-Brain (Simeone et al., 1994; Turner et al., 1994; Bulfone et al., 1995).

Olf-1 is found in cells arising from embryonically distinct origins, including neural tube, neural crest, and placodes, suggesting that Olf-1 may participate in a basic process in neurogenesis common to many different neuronal cell types as well as play an additional role in the specification of neuronal phenotype in the olfactory neuron. Furthermore, where it is possible to distinguish, Olf-1 is expressed in neuronal precursors of sensory structures, including the retina, inner ear, OE, sensory ganglia, and dorsal column of the neural tube. We have not detected Olf-1 protein in identifiable structures mediating motor functions.

\section{Pax-6 protein in OE and retina}

Previous in situ hybridization analysis of murine Pax-6, a pairedbox- and homeodomain-containing protein, showed that Pax-6 mRNA was present in the embryonic nervous system, including distinct regions of the brain, neural tube, eye, pituitary, and $\mathrm{OE}$ (Walther and Gruss, 1991). The early embryonic onset and its exclusive expression in ectodermally derived tissue made Pax-6 a candidate regulatory molecule in the development of the CNS. The generation of a Pax-6-specific antibody and the analysis reported here demonstrate that in contrast to neuronally expressed Olf-1, Pax-6 protein is localized to non-neuronal cells in the olfactory system, including the nuclei of sustentacular cells, a subset of basal cells, and a subset of cells in the Bowman's glands. In addition, Pax-6 protein is detected in cornea, lens, and cells of the optic vesicle of the developing eye. In the mature mouse retina, Pax-6 is expressed in cells of the GCL and INuL, consistent with the localization of Pax-6 mRNA in the adult quail retina (Martin et al., 1992).

Two classes of basal cells can be distinguished in the OE on the basis of their location, morphology, immunohistochemical reac- tivity, and distinct roles in OE development (Cuschieri and Bannister, 1975a,b; Vollrath et al., 1985; Calof and Chikaraishi, 1989; Levey et al., 1991; Suzuki and Takeda, 1991; Caggiano et al., 1994). Pax-6-positive cells located in the bottom-most layer of the epithelium are NCAM-negative, suggesting that HBCs, but not GBCs, express Pax-6. The shapes of Pax-6-positive HBCs range from pyramidal to flat, possibly as a function of their proliferative status (Suzuki and Takeda, 1991). By E14, Pax-6 is expressed in cells with a wine-glass shape characteristic of the sustentacular cells that line the luminal surface of the OE (Cuschieri and Bannister, 1975a). Cells in the lamina propria, corresponding to Bowman's glands, are immunoreactive with the Pax- 6 antibody by E16 (Bojsen-Moller, 1964; Cuschieri and Bannister, 1975b). Additionally, scattered Pax-6-positive nuclei in the middle of the epithelium were observed and may reflect a migration of cells from the HBC population to the apical, sustentacular cell layer. Localization of Pax-6 to sustentacular cells, HBCs, Bowman's glands, and a few cells in the middle of the epithelium may reflect a relationship between the four cell types and is consistent with a progenitor role for HBCs and/or Bowman's glands in the establishment of the sustentacular cell population (Mulvaney and Heist, 1971; Hempstead and Morgan, 1983; Suzuki and Takeda, 1991). Several other markers colocalize in these cell types, including SUS-1 and a collection of cytokeratins (Hempstead and Morgan, 1983; Vollrath et al., 1985; Levey et al., 1991). Indirect evidence from retroviral lineage analysis in adult OE, however, suggests a sustentacular lineage distinct from HBCs (Caggiano et al., 1994). The absence of expression of Pax-6 in any cells of the neuronal lineage makes it unlikely that the rare Pax-6-positive cells in the middle of the epithelium represent immediate neuronal precursors (Calof and Chikaraishi, 1989; DeHamer et al., 1994).

Differentiation of the olfactory organ from the ectodermally derived olfactory placode is a complex process that involves formation of sensory neurons as well as several types of non-neuronal cells, including sustentacular cells and Bowman's glands. In most vertebrates, the cells of the embryonic ectoderm are similar morphologically, making it difficult to identify subpopulations of cells that will give rise to neuronal versus non-neuronal progeny (Waterman and Meller, 1973; Cuschieri and Bannister, 1975a,b; Klein and Graziadei, 1983). The localization of Pax-6 to sustentacular cells, basal cells, and Bowman's glands may reflect their common embryonic origins, possibly from the non-neuronal component of the embryonic ectoderm. The importance of Pax- 6 in mouse development is suggested by Sey mice, in which animals homozygous for a mutation in the Pax- 6 gene fail to form olfactory and lens placodes (Thieler et al., 1978; Hogan et al., 1986), and recent analysis has confirmed the expression of Pax- 6 mRNA in the nasal placodes (Grindley et al., 1995). Pax-6 may be required early in placode formation and later in the regulation of non-neuronal, lineage-specific genes. An examination of olfactory placode development using our Pax-6 antibody, in conjunction with a neuronal cell marker such as Mash-1, will allow us to determine the time course and spatial pattern of Pax-6 protein expression within the developing placode. The nonoverlapping cellular localization pattern of Pax-6 and Olf-1 make it unlikely that these factors interact directly with each other. Rather, these proteins may demarcate distinct cell lineages within the developing epithelium and permit a clearer understanding of olfactory organ development. 


\section{REFERENCES}

Altman J, Bayer SA (1979) Development of the diencephalon in the rat. J Comp Neurol 188:455-500.

Altman J, Bayer SA (1984) The development of the rat spinal cord. Adv Anat Embryol Cell Biol 85:53-83.

Altman J, Bayer SA (1985) Embryonic development of the rat cerebellum. J Comp Neurol 194:1-35.

Altman J, Bayer SA (1988) Development of the rat thalamus. I. Mosaic organization of the thalamic neuroepithelium. J Comp Neurol 275:346-377.

Angevine JB (1970) Time of neuron origin in the diencephalon of the mouse: an autoradiographic study. J Comp Neurol 139:129-188.

Angevine JB, Sidman RL (1961) Autoradiographic study of cell migration during histogenesis of cerebral cortex in the mouse. Nature 192:766-768.

Barber PC, Raisman G (1974) An autoradiographic investigation of the projection of the vomeronasal organ to the accessory olfactory bulb in the mouse. Brain Res 81:21-30.

Bojsen-Moller F (1964) Topography of the nasal glands in rats and some other mammals. Anat Rec 150:11-24.

Bulfone A, Smiga SM, Shimamura K, Peterson A, Puelles L, Rubenstein JLR (1995) T-Brain-1: a homolog of Brachyury whose expression defines molecularly distinct domains within the cerebral cortex. Neuron 15:63-78.

Caggiano M, Kauer JS, Hunter DD (1994) Globose basal cells are neuronal progenitors in the olfactory epithelium: a lineage analysis using a replication-incompetent retrovirus. Neuron 13:339-352.

Calof AL (1995) Intrinsic and extrinsic factors regulating vertebrate neurogenesis. Curr Opin Neurobiol 5:19-27.

Calof AL, Chikaraishi DM (1989) Analysis of neurogenesis in a mammalian neuroepithelium: proliferation and differentiation of an olfactory neuron precursor in vitro. Neuron 3:115-127.

Costanzo RM, Graziadei PPC (1987) Development and plasticity of the olfactory system. In: Neurobiology of taste and smell (Silver W, ed), pp 233-250. New York: Wiley.

Cuschieri A, Bannister LH (1975a) The development of the olfactory mucosa in the mouse: electron microscopy. J Anat 119:471-498.

Cuschieri A, Bannister LH (1975b) The development of the olfactory mucosa in the mouse: light microscopy. J Anat 119:277-286.

DeHamer MK, Guevara JL, Hannon K, Olwin BB, Calof AL (1994) Genesis of olfactory receptor neurons in vitro: regulation of progenitor cell divisions by fibroblast growth factors. Neuron 13:1083-1097.

Glaser T, Walton DS, Maas RL (1992) Genomic structure, evolutionary conservation and aniridia mutations in the human $P A X 6$ gene. Nature Genet 2:232-238.

Graziadei PPC, Monti Graziadei GA (1978) The olfactory system: a model for the study of neurogenesis and axon regeneration in mammals. New York: Raven.

Grindley JC, Davidson DR, Hill RE (1995) The role of Pax-6 in eye and nasal development. Development 121:1433-1442.

Gruss P, Walther C (1992) Pax in development. Cell 69:719-722.

Guillemot F, Joyner AL (1993) Dynamic expression of the murine achaete-scute homologue Mash-1 in the developing nervous system. Mech Dev 42:171-185.

Guillemot F, Lo L-C, Johnson JE, Auerbach A, Anderson DJ, Joyner AL (1993) Mammalian achaete-scute homolog 1 is required for the early development of olfactory and autonomic neurons. Cell 75:463-476.

Hagman J, Belanger C, Travis A, Turck C, Grosschedl R (1993) Cloning and functional characterization of early B-cell factor, a regulator of lymphocyte specific gene expression. Genes Dev 7:760-773.

Hanson IM, Seawright A, Hardman K, Hodgson S, Zaletayev D, Fekete G, Heyningen V (1993) PAX6 mutations in aniridia. Hum Mol Genet 2:915-920.

Hempstead JL, Morgan JI (1983) Monoclonal antibodies to the rat olfactory sustentacular cell. Brain Res 288:289-295.

Hill RE, Favor J, Hogan BLM, Ton CCT, Saunders GF, Hanson IM, Prosser J, Jordan T, Hastie ND, Heyningen V (1991) Mouse small eye results from mutations in a paired-like homeobox-containing gene. Nature 354:522-525.

Hogan BLM, Horsburgh G, Cohen J, Hetherington CM, Fisher G, Lyon MF (1986) Small eyes (Sey): a homozygous lethal mutation on chromosome 2 which affects the differentiation of both lens and nasal placodes in the mouse. J Embryol 97:95-110.
Kaufman MH (1992) The atlas of mouse development. New York: Harcourt Brace Jovanovich.

Klein SL, Graziadei PPC (1983) The differentiation of the olfactory placode in Xenopus laevis: a light and electron microscope study. J Comp Neurol 217:17-30.

Kudrycki K, Stein-Izsak C, Behn C, Grillo M, Akeson R, Margolis FL (1993) Olf-1 binding site: characterization of an olfactory specific promoter motif. Mol Cell Biol 13:3002-3014.

Lee JE, Hollenberg SM, Snider L, Turner DL, Lipnick N, Weintraub H (1995) Conversion of Xenopus ectoderm into neurons by NeuroD, a basic helix-loop-helix protein. Science 268:836-844.

Levey MS, Chikaraishi DM, Kauer JS (1991) Characterization of potential precursor populations in the mouse olfactory epithelium using immunocytochemistry and autoradiography. J Neurosci 11:3556-3564.

Lin H, Grosschedl R (1995) Failure of B-cell differentiation in mice lacking the transcription factor EBF. Nature 376:263-267.

Mackay-Sim A, Kittel P (1991) Cell dynamics in the adult mouse olfactory epithelium: a quantitative autoradiographic study. J Neurosci 11:979-984.

Mahanthappa NK, Schwarting GA (1993) Peptide growth factor control of olfactory neurogenesis and neuron survival in vitro: roles of EGF and TGF- $\beta$ s. Neuron 10:293-305.

Margalit T, Lancet D (1993) Expression of olfactory receptor and transduction genes during rat development. Brain Res Dev Brain Res 73:7-16.

Martin P, Carriere C, Dozier C, Quatannens B, Mirabel M-A, Vandenbunder B, Stehelin D, Saule S (1992) Characterization of a paired boxand homeobox-containing quail gene $(\operatorname{Pax}-Q N R)$ expressed in the neuroretina. Oncogene 7:1721-1728.

Miragall F, Kadmon G, Husmann M, Schachner M (1988) Expression of cell adhesion molecules in the olfactory system of the adult mouse: presence of the embryonic form of N-CAM. Dev Biol 129:516-531.

Moulton DG (1974) Dynamics of cell populations in the olfactory epithelium. Ann NY Acad Sci 237:52-61.

Mulvaney BD, Heist HE (1971) Regeneration of rabbit olfactory epithelium. Am J Anat 131:241-252.

Nornes HO, Carry M (1978) Neurogenesis in spinal cord of mouse: an autoradiographic analysis. Brain Res 159:1-16.

Pellier V, Astic L, Oesterreicher AB, Saucier D (1994) B-50/GAP-43 expression by the olfactory receptor cells and the neurons migrating from the olfactory placode in embryonic rats. J Brain Res 80:63-72.

Price M, Lemaistre M, Pischetola M, Lauro RD, Duboule D (1991) A mouse gene related to Distal-less shows a restricted expression in the developing forebrain. Nature 351:748-751.

Roskams AJ, Bethel MA, Hurt KJ, Ronnett GV (1996) Sequential expression of Trks A, B and C in the regenerating olfactory neuroepithelium. J Neurosci 16:1294-1307.

Rudnicki MA, Schnegelsberg PNJ, Stead RH, Braun T, Arnold H, Jaenisch R (1993) MyoD or Myf-5 is required for the formation of skeletal muscle. Cell 75:1351-1359.

Sauer FC (1935) Mitosis in the neural tube. J Comp Neurol 62:377-405.

Schwanzel-Fukuda M, Pfaff DW (1989) Origin of luteinizing hormonereleasing hormone neurons. Nature 338:161-163.

Schwanzel-Fukuda M, Pfaff DW (1990) The migration of luteinizing hormone-releasing hormone (LHRH) neurons from the medial olfactory placode into the medial basal forebrain. Experientia 46:956-962.

Shipley MT, Smith DV (1995) The olfactory system. In: Neuroscience in medicine (Conn PM, ed), pp 521-524. Philadelphia: JB Lippincott.

Sidman RL (1970) Cell proliferation, migration and interaction in the developing mammalian central nervous system. In: The neurosciences, a second study program, (Schmitt GCQFO, Melnechuk T, Adelman G, eds), pp 100-107. New York: Rockefeller UP.

Sidman RL, Miale IL, Feder N (1959) Cell proliferation and migration in the primitive ependymal zone: an autoradiographic study of histogenesis in the nervous system. Exp Neurol 1:322-333.

Simeone A, D'Apice MR, Nigo V, Casanova J, Graziani F, Acampora D, Avantaggiato V (1994) Orthopedia, a novel homeobox-containing gene expressed in the developing CNS of both mouse and Drosophila. Neuron 13:83-101.

Smart IHM (1971) Location and orientation of mitotic figures in the developing mouse olfactory epithelium. J Anat 109:243-251. 
Suzuki Y, Takeda M (1991) Basal cells in the mouse olfactory epithelium after axotomy: immunohistochemical and electron-microscopic studies. Cell Tissue Res 266:239-245.

Thieler K, Varnum DS, Stevens LC (1978) Development of Dickie's small eye, a mutation in the house mouse. Anat Embryol 155:81-86.

Treacy MN, He X, Rosenfeld MG (1991) I-POU: a POU-domain protein that inhibits neuron-specific gene activation. Nature 350:577-584.

Turner DL, Cepko CL (1987) A common progenitor for neurons and glia persists in rat retina late in development. Nature 328:131-136.

Turner DL, Snyder EY, Cepko CL (1990) Lineage-independent determination of cell type in the embryonic mouse retina. Neuron 4:833-845.

Turner EE, Jenne KJ, Rosenfeld MG (1994) Brn-3.2: a Brn-3-related transcription factor with distinctive central nervous system expression and regulation by retinoic acid. Neuron 12:205-218.

Vollrath M, Altmannsberger M, Weber K, Osborn M (1985) An ultrastructural and immunohistological study of the rat olfactory epi- thelium: unique properties of olfactory sensory cells. Differentiation 29:243-253.

Walther C, Gruss P (1991) Pax-6, a murine paired box gene, is expressed in developing CNS. Development 113:1435-1449.

Wang MM, Reed RR (1993) Molecular cloning of the olfactory neuronal transcription factor Olf-1 by genetic selection in yeast. Nature 364:121-126.

Wang MM, Tsai RYL, Schrader KA, Reed RR (1993) Genes encoding components of the olfactory signal transduction cascade contain a DNA binding site that may direct neuronal expression. Mol Cell Biol 13:5805-5813.

Waterman RE, Meller SM (1973) Nasal pit formation in the hamster: a transmission and scanning electron microscopic study. Dev Biol 34:255-266.

Young RW (1985) Cell differentiation in the retina of the mouse. Anat Rec 212:199-205. 